\title{
PENGARUH PEMBERIAN KETAMIN TERHADAP JUMLAH SEL MAKROFAG PADA GINJAL TIKUS PUTIH DARI GALUR WISTAR MODEL SEPSIS
}

\author{
Bagus Fajar Rohman', Aswoco Andyk Asmoro', Djudjuk Rahmad Basuki ${ }^{1}$ \\ ${ }^{1}$ Fakultas Kedokteran Universitas Brawijaya Malang
}

\author{
Email : goesdoct@gmail.com
}

\begin{abstract}
ABSTRAK
Latar Belakang. Paparan LPS yang akan menyebabkan terjadinya sepsis digambarkan dengan adanya pelepasan sitokin proinflamasi seperti TNF-á, IL-1â, IL-8 yang berhubungan dengan kerusakan endotel dan jaringan. Ketamin mensupresi produksi LPS-induced TNF- , IL-6 dan IL-8 dan rhTNF-induced IL-6 and IL-8 dalam darah manusia. Tujuan. Mengetahui pengaruh pemberian ketamin terhadap jumlah sel makrofag ginjal dan pengaruh perbedaan waktu dan cara pemberian pemberian ketamin terhadap sel makrofag tikus. Metode. Penelitian menggunakan metode experimental, dengan sampel hewan coba tikus putih rattus norvegicus dari galur wistar model sepsis menggunakan metode fecal induced peritonitis (FIP). Sampel dibagi menjadi enam kelompok perlakuan yaitu : kontrol negatif (-), kontrol positif (+), pemberian ketamin $5 \mathrm{mg} /$ kgbb pada jam ke-0 (A), ke-3 (B), ke-5 (C) dan pemberian berturut-turut pada jam ke 0,2,4 (D). Analisa data menggunakan anova dan post hoc test. Hasil. Analisis anova diperoleh nilai signifikansi sebesar $0,000(\mathrm{p}<0,05)$ yang menunjukkan ada perbedaan bermakna rerata antar tiap kelompok perlakuan. Hasil uji post hoc test didapat nilai signifikansi yang berbeda yang menunjukkan waktu pemberian ketamin berpengaruh positif terhadap jumlah makrofag ginjal tikus model sepsis. Kesimpulan. Waktu dan cara pemberian ketamin berpengaruh positif terhadap jumlah makrofag ginjal tikus serta terdapat perbedaan jumlah makrofag pada setiap kelompok perlakuan pemberian ketamin.
\end{abstract}

Kata Kunci. Ketamin, makrofag, ginjal

\begin{abstract}
Background. LPS Exposure will cause sepsis is described by the release of proinflammatory cytokines such as TNF-á, IL-1â, IL-8 which are associated with endothelial and tissue damage. Ketamine suppresses the production of LPS-induced TNF-, IL-6 and IL-8 and rbTNFinduced IL-6 and IL-8 in human blood. Objective. This study was to evaluate difference in numbers of makrophage in kidney mice and the influence of ketamine administration time Methods. This study used an experimental method, with animal samples of rattus norvegicus white mice from the septic model wistar strain using fecal induced peritonitis (FIP) method. Samples divided into six groups: negative control $(-)$, positive control (+), administration of ketamine $5 \mathrm{mg} / \mathrm{kg}$ at hour $0(A), 3 \mathrm{rd}(B), 5$ th $(C)$ and every two hour to 0.2.4 (D). Data analysis uses anova and post hoc test. Results. anova analysis obtained a significance value of $0.000(p<0.05)$ which showed there were significant differences between each group. The results of the post hoc test obtained different significance values which showed the timing of administration of ketamine had a positive effect on the number of renal macrophages in sepsis models of rats. Conclusion. The time and method of administration of ketamine have a positive effect on the number of renal macrophages and there are differences in the number of macrophages in each treatment group given ketamine.
\end{abstract}

Keywords. Ketamine, macrophages, renal 


\section{PENDAHULUAN}

Sepsis adalah sindrom klinis kompleks yang ditandai dengan respons inflamasi sistemik terhadap infeksi. Proses ini sering memicu meluasnya kerusakan jaringan dan disfungsi berbagai organ. Gagal ginjal akut (AKI) adalah salah satu komplikasi yang paling sering terjadi, yang meningkatkan biaya dan kompleksitas perawatan, dan merupakan faktor risiko terjadinya kematian (Umbro Ilaria et al, 2015). Sepsis menyumbangkan lebih dari 250.000 kematian setiap tahun di United States dan 5.3 juta kematian diseluruh dunia. (Hotchkiss et al, 2013, Fleischmann et al, 2015 ).

Sepsis disebabkan oleh mikroorganisme seperti bakteri gram negatif maupun positif, jamur, virus dan parasit (James et al., 2005). Bakteri gram negatif menjadi penyebab terbesar dari kasus sepsis yaitu 30\%-80\% sedangkan bakteri gram positif antara 6\%-24\% (Edwin et al.,2003). Komponen utama dari bakteri gram negatif yang berperan penting terhadap sepsis adalah lipopolisakarida (LPS). LPS atau endotoksin glikoprotein kompleks merupakan bagian utama membran terluar dari bakteri gram negative. LPS langsung mengaktifkan sistem imun seluler maupun humoral yang dapat menimbulkan perkembangan septicemia. LPS memicu sitokin proinflamasi melalui aktivasi gen nuclear factor k-B (NF-kB) (Guntur, 2006). Monosit dan makrofag memainkan peranan utama pada permulaan dan pemeliharaan respons imun terhadap patogen dan respons inang terhadap tumor, sebagian melalui sekresi beberapa produk poten dan sitokin makrofag. Monosit dan makrofag jaringan menghasilkan sedikitnya dua kelompok protein mediator inflamasi yaitu interleukin 1 (IL1) dan Tumor Necrosis Factor (TNF) (Giocomini et al., 2001; Han et al., 2002).

Ketamin adalah obat anestesi yang mempunyai efek stimulasi terhadap kardiovaskuler, meningkatkan cardiac output dan systemic vaskuler resistance melalui stimulasi pada system saraf simpatis, menghasilkan pelepasan dari katekolamin (Loix, 2011). Ketamin mensupresi produksi LPS-induced TNF- , IL6 dan IL-8 dan rhTNF-induced IL-6 and IL-8 dalam darah manusia. TNF- adalah sitokin pertama yang timbul setelah stimulasi LPS, yang kemudian menstimulasi sekresi IL-6 and IL-8 dari makrofag monosit, neutrofil, dan sel endotel. Supresi ketamin pada produksi LPS induced IL-6 and IL-8 disebabkan efek inhibisi ketamin pada produksi LPS-induced TNF(Danielle P.K.et.al,2005;Yi Chang.et.al 2005;Kawasaki C.et.al.2001).

Kemampuan ketamin menurunkan sitokin proinflamasi seperti IL-6, IL-* dan TNF dan NF-kB sebagai anti inflamasi diharapkan mampu menggurangi SIRS. Salah satu organ yang paling sering mengalami kegagalan fungsi akibat sepsis adalah ginjal (Bonventre JV,2004). Pemberian ketamin secara intra peritoneal diharapkan dapat menurunkan jumlah makrofag diginjal yang selanjutnya akan menngurangi terjadinya disfungsi ginjal sehingga dapat menurunkan morbiditas maupun mortalitas akibat sepsis.

\section{METODE PENELITIAN}

Penelitian ini merupakan penelitian experimental dengan desain true experimental laboratory dengan metode Randomized Posttest Only Controlled Group Design. Sampel menggunakan hewan coba tikus putih Rattus Norvegicus dari galur wistar dengan kriteria inklusi tikus jantan, sehat umur 5 bulan, berat badan 200-250 gram, dan belum mengalami perlakuan apapun. Jumlah sampel sebanyak 30 ekor tikus yang dibagi menjadi enam (6) kelompok perlakuan yaitu $\mathrm{KN}(-)$ kelompok kontrol negatif tikus yang tidak mendapat perlakuan apapun, $\mathrm{KN}(+)$ kelompok kontrol positif tikus yang diinduksi sepsis dengan metode Fecal Induced Peritonitis (FIP) namun tidak diberikan ketamin, $\mathrm{KP}(\mathrm{A})$ : Tikus yang diinduksi sepsis dan diberikan ketamin $5 \mathrm{mg} / \mathrm{kgbb}$ intraperitoneal pada jam ke $0, \mathrm{KP}(\mathrm{B})$ : Tikus yang diinduksi sepsis dan diberikan ketamin $5 \mathrm{mg} / \mathrm{kgbb}$ intraperitoneal pada jam ke $3, \mathrm{KP}(\mathrm{C})$ : Tikus yang diinduksi sepsis dan diberikan ketamin $5 \mathrm{mg} / \mathrm{kgbb}$ intraperitoneal pada jam ke 5, KP(D) : Tikus yang diinduksi sepsis dan diberikan ketamin dosis $5 \mathrm{mg} /$ kgbb intraperitoneal tiap 2 jam (jam ke 0,2,4). Pada jam ke-6 setelah pemberian FIP dilakukan pembedahan tikus untuk diamati jumlah makrofag pada jaringan ginjal tikus.

Uji komparasi kelompok, dilakukan dengan uji one-way anova, apabila setelah dilakukan uji prasyarat parametrik didapatkan hasil sebaran data normal. Apabila pada uji prasyarat parametrik, didapatkan hasil sebaran data tidak normal akan dilakukan uji non parametrik yaitu uji Kruskal Wallis. 


\section{HASIL PENELITIAN}

Hasil pengamatan mikroskopis terhadap jumlah makrofag ginjal pada tiap kelompok dapat dilihat pada tabel berikut :

Tabel 1. Pembagian Kelompok Perlakuan

\begin{tabular}{ccccccc}
\hline No & \multicolumn{7}{c}{ Kelompok } \\
\cline { 2 - 7 } & $\mathbf{N}$ & $\mathbf{P}$ & $\mathbf{A}$ & $\mathbf{B}$ & $\mathbf{C}$ & $\mathbf{D}$ \\
$\mathbf{1}$ & 19 & 47 & 46 & 22 & 15 & 10 \\
$\mathbf{2}$ & 15 & 45 & 39 & 26 & 8 & 19 \\
$\mathbf{3}$ & 22 & 33 & 51 & 24 & 10 & 10 \\
$\mathbf{4}$ & 18 & 35 & 39 & 16 & 9 & 9 \\
$\mathbf{5}$ & 20 & 43 & 30 & 14 & 15 & 7 \\
\hline
\end{tabular}

Berdasarkan rata-rata dapat dikatakan bahwa perlakuan D (Tikus yang dilakukan induksi sepsis dengan metode FIP jam ke 0 dan dilakukan pemberian ketamin dengan dosis $5 \mathrm{mg} / \mathrm{kgbb}$ intraperitoneal tiap 2 jam (jam ke $0,2,4)$ ) merupakan perlakuan yang paling baik dalam menurunkan jumlah makrofg pada ginjal tikus yang telah terinduksi sepsis.

Hasil analisis anova didapat nilai signifikasi 0,000 yang berarti terdapat perbedaan yang signifikan jumlah makrofag ginjal tikus pada minimal 1 kelompok. Post Hoc Test merupakan analisis lanjutan dalam uji anova. Hasil uji Post Hoc Test ditampilkan pada tabel berikut :

Tabel 2. Hasil Uji Post Hoc Test

\begin{tabular}{llcc}
\hline No & Perbandingan perlakuan & Nilai Sig. & Ke terangan \\
\hline $\mathbf{1}$ & $\mathrm{K}(-)-\mathrm{K}(+)$ & 0,000 & Berbeda signifikan \\
$\mathbf{2}$ & $\mathrm{K}(-)-\mathrm{A}$ & 0,000 & Berbeda signifikan \\
$\mathbf{3}$ & $\mathrm{K}(-)-\mathrm{B}$ & 1,000 & Tidak Berbeda signifikan \\
$\mathbf{4}$ & $\mathrm{K}(-)-\mathrm{C}$ & 0,036 & Berbeda signifikan \\
$\mathbf{5}$ & $\mathrm{K}(-)-\mathrm{D}$ & 0,021 & Berbeda signifikan \\
$\mathbf{6}$ & $\mathrm{K}(+)-\mathrm{A}$ & 1,000 & Tidak Berbeda signifikan \\
$\mathbf{7}$ & $\mathrm{K}(+)-\mathrm{B}$ & 0,001 & Berbeda signifikan \\
$\mathbf{8}$ & $\mathrm{K}(+)-\mathrm{C}$ & 0,000 & Berbeda signifikan \\
$\mathbf{9}$ & $\mathrm{K}(+)-\mathrm{D}$ & 0,000 & Berbeda signifikan \\
$\mathbf{1 0}$ & $\mathrm{A}-\mathrm{B}$ & 0,001 & Berbeda signifikan \\
$\mathbf{1 1}$ & $\mathrm{A}-\mathrm{C}$ & 0,000 & Berbeda signifikan \\
$\mathbf{1 2}$ & $\mathrm{A}-\mathrm{D}$ & 0,000 & Berbeda signifikan \\
$\mathbf{1 3}$ & $\mathrm{B}-\mathrm{C}$ & 0,009 & Berbeda signifikan \\
$\mathbf{1 4}$ & $\mathrm{B}-\mathrm{D}$ & 0,005 & Berbeda signifikan \\
$\mathbf{1 5}$ & $\mathrm{C}-\mathrm{D}$ & 1,000 & Tidak Berbeda signifikan \\
\hline
\end{tabular}

Perlakuan pemberian ketamine yang baik dilihat dari jumlah makrofag pada ginjal tikus terendah adalah perlakuan $\mathrm{B}$, perlakuan $\mathrm{C}$ dan perlakuan $\mathrm{D}$ karena hasil pengujian menunjukkan bahwa ketiga perlakuan ini memiliki jumlah makrofag ginjal yang tidak berbeda signifikan dan lebih rendah dengan perlakuan kontrol (-), sedangkan perlakuan yang tidak dianjurkan adalah perlakuan A karena dari hasil analisis perlakuan ini memiliki jumlah makrofag tidak berbeda signifikan dengan kontrol (+) di mana jumlah makrofag pada ginjalnya masih tinggi.

\section{DISKUSI}

Sepsis merupakan salah satu penyebab terjadinya kerusakan ginjal akut. Dimana kerusakan ginjal akut juga dapat memodulasi sistem imun yang dapat menimbulkan kerusakan ginjal lebih lanjut. Disfungsi endotel sebagai hasil dari 
hilangnya autoregulasi aliran darah ginjal, dan adanya degradasi glikokaliks berkontribusi pada peningkatan permeabilitas vaskular dan peningkatan rolling / adhesi leukosit dan trombosit. Kombinasi dari kedua faktor ini menyebabkan makrofag dan neutrofil teraktivasi untuk menghasilkan sitokin proinflamasi (bonavia A,2017)

Faktor transkripsi
pF-kB mempunyai Aktivasi NF-kB dapat menuju kearah transkripsi dari protein-protein proinflamasi. Ketamin menghambat aktivasi NF-kB melalui penekanan degradasi IkB-á dan translokasi NF-kB sehingga akan menghambat produksi sitokain proinflamasi. Ketamin mensupresi produksi LPS-induced TNF, IL-6 dan IL-8 dan rhTNF-induced IL-6 and IL8 dalam darah manusia. TNF- adalah sitokin pertama yang timbul setelah stimulasi LPS, yang kemudian menstimulasi sekresi IL-6 and IL-8 dari makrofag monosit, neutrofil, dan sel endotel. Supresi ketamin pada produksi LPS induced IL6 and IL-8 disebabkan efek inhibisi ketamin pada produksi LPS-induced TNF- .

Pada penelitian ini, kelompok kontrol negative $(\mathrm{N})$ menunjukkan jumlah rerata makrofag 18.8. Beberapa diantaranya menunjukkan jumlah makrofag sampai 22 . Hal ini kemungkinan karena adanya variabel luar yang tidak dapat dikendalikan seperti kepekaan mencit terhadap suatu zat, kondisi psikologis mencit, maupun kondisi awal ginjal mencit.

Pemberian material Fecal Induced Peritonitis (FIP) pada kelompok kontrol positif (P) menyebabkan meningkatnya jumlah makofag tikus secara bermakna. Pemberian material secara FIP menggambarkan keadaan klinis peritonitis yang disebabkan infeksi mikroba, adanya infeksi kuman patogen tersebut pada subjek penelitian merupakan penyebab terjadinya sepsis (Kirsten, $\mathrm{P} e t$ al. 2003).

Pemberian ketamine langsung setelah keadaan sepsis pada jam ke - 0 (kelompok A) tidak dapat menurunkan jumlah makrofag pada ginjal tikus secara bermakna. Kelompok ini memperlihatkan sebagian besar tikus menunjukkan jumlah makrofag ginjal yang hampir sama dengan kelompok pada kontrol positif. Namun pada kelompok tikus yang diberikan ketamine 3 jam (kelompok B) dan 5 jam (kelompok C) dan kelompok dengan pemberian intermitten setiap 2 jam ( kelompok D) sesudah di induksi FIP menunjukkan sebagian besar tikus telah mengalami penurunan jumlah makrofag pada ginjal tikus secara bermakna dibandingkan dengan kelompok kontrol positif.. Hasil pengujian statistic menggunakan Anova bahwa perlakuan yang tidak berbeda signifikan yaitu $\mathrm{K}(-)$ dengan perlakuan $\mathrm{B}$, , $\mathrm{K}(+)$ dengan perlakuan $A$, perlakuan $C$ dengan perlakuan $D$. Artinya perlakuan pemberian ketamine yang baik yang akan menghasilkan jumlah makrofag tikus yang sama atau lebih sedikit dibandingkan dengan kontrol (-) adalah perlakuan B, perlakuan C dan perlakuan D. karena hasil pengujian menunjukkan bahwa perlakuan B memiliki jumlah makrofag yang tidak berbeda signifikan dengan perlakuan kontrol (-) sehingga kelompok perlakuan B ini adalah yang dianjurkan karena paling sesuai dengan kondisi fisiologis tubuh. Sedangkan perlakuan C dan perlakuan D menurunkan jumlah makrofag ginjal paling baik. Sedangkan perlakuan yang tidak dianjurkan adalah perlakuan A karena dari hasil analisis kedua perlakuan ini memiliki jumlah makrofag pada ginjal yang tidak berbeda signifikan dengan kontrol $(+)$ di mana jumlah makrofag pada ginjalnya masih tinggi.

\section{SIMPULAN}

Terjadi peningkatan jumlah sel makrofag pada tikus model sepsis yang diinduksi dengan Fecal Induced Peritonitis (FIP). Pemberian intermitten ketamin tiap 2 jam pada grup D dapat menurunkan jumlah makrofag paling baik pada tikus model sepsis yang diinduksi dengan Fecal Induced Peritonitis (FIP). Pemberian ketamin dengan waktu yang berbeda dapat mempengaruhi jumlah sel makrofag pada tikus model sepsis yang diinduksi dengan Fecal Induced Peritonitis (FIP).

\section{DAFTAR PUSTAKA}

Bonavia A, singbartl K, 2017. A review of the role of immune cells in acute kidney injury. Pediatric nephrology, 10(4), p.1-7

Bonventre JV. Pathophysiology of ischemic acute renal failure. In: Ronco C, Bellomo R, Brendolan A, eds. Sepsis, kidney, and multiple organ dysfunction. Contrib nephrol. Basel: Karger; 2004. p. 19-30 
Danielle P K, Bull S, Duk P V, Gremmels J, Hellebrekers L. Ketamin inhibits LPS-induce Tumor Necrosis Faktor-alpha and Interleukin-6 in an Equine Macrophag Cell Line. Section Anesthesiologi and Intensive Care, Utrecht University; 2005: 257-62

Guntur AH. The Role Cytokine of the Pathogenesis of SIRS - Sepsis. Perspektif Masa Depan Imunologi Infeksi. International Journal on Immunorehabilitation $2003 ; 4: 23-0$.

Gurfinkel R., Czeiger D., Douvdevani A., Shapira Y., Artru A.A., Sufaro Y., et al., 2006. Ketamine improves survival in burn injury followed by sepsis in rats, Anesthesia \& Analgesia, 103(2): pp. 396-402.

Han,Hwa.et al.2017. The role of macrophages during acute kidney injury: destruction and repair. https://doi.org/10.1007/s00467-0173883-1.

Hirota K. dan Lambert D. 2011, 'Ketamine: new uses for an old drug?'. British Jrnl Anaesthesia.

Kirsten, P et al. 2003. Molecular basis of endothelial dysfunction in sepsis. Cardiovascular Research 60 (2003) 49-57.

Loix S., De Kock M. dan Henin P., 2011. The antiinflammatory effects of ketamine: state of the art, Acta Anaesthesiol Belg, 62(1): pp. 4758.

Tripathi P. dan Aggarwal A., 2006. NF-kB transcription factor: a key player in the generation of immune response, CURRENT SCIENCE-BANGALORE-, 90(4): p. 519. 